\title{
Pengaruh Layanan Bimbingan Kelompok Teknik Role Playing Terhadap Interaksi Sosial
}

\author{
Nanda Anggoro Kasih Wibowo, Bambang Susanto, Muhammad Arief Maulana \\ Program Studi Bimbingan dan Konseling, Universitas Veteran Bangun Nusantara \\ Email: maulgonzales89@gmail.com
}

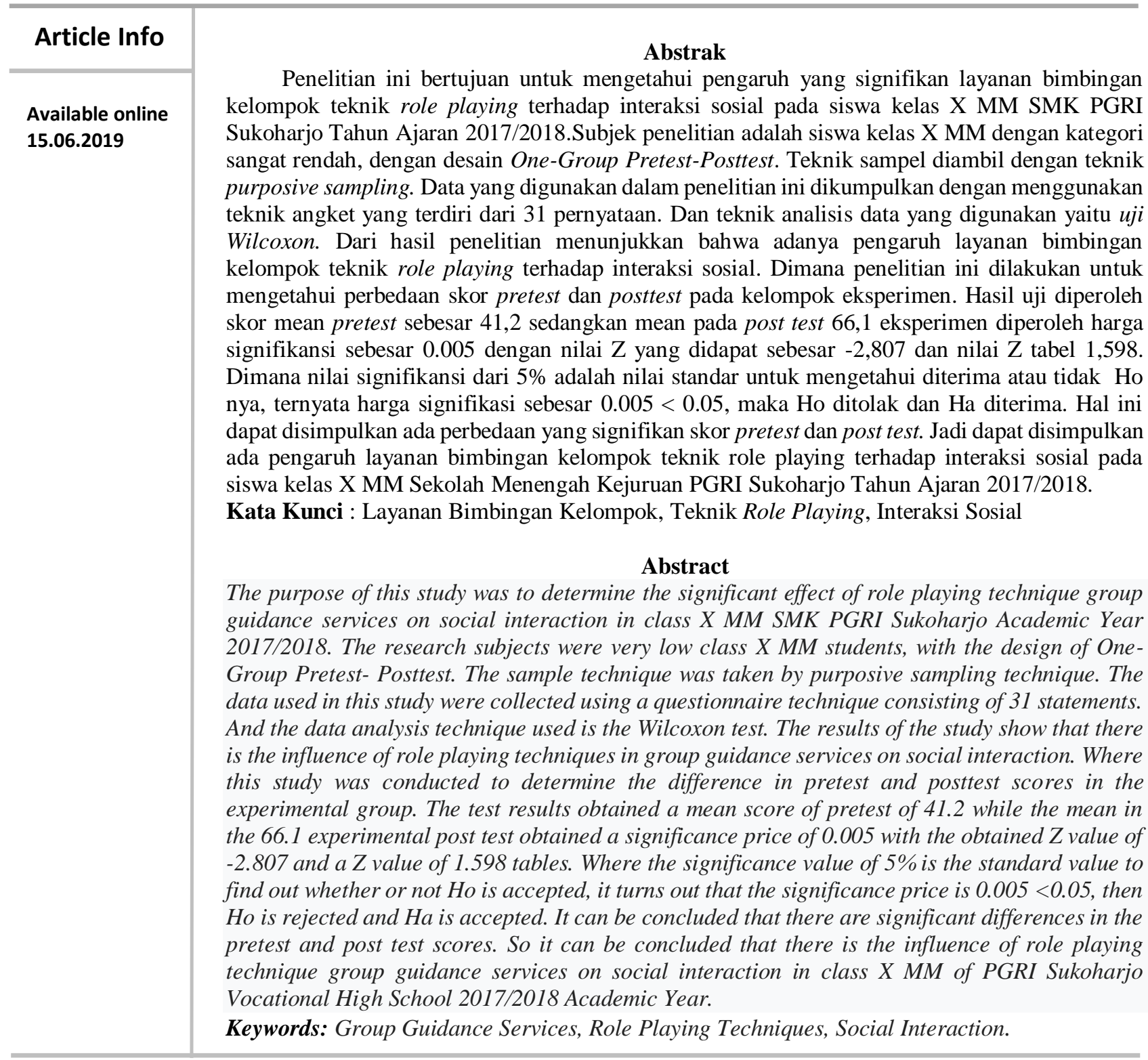

\section{PENDAHULUAN}

Manusia pada dasarnya merupakan makhluk sosial yang dimana mereka tidak dapat hidup sendiri namun membutuhkan bantuan oleh orang lain. Hal tersebut akan mendorong manusia untuk selalu berbagi dan saling membantu satu sama lain. Agar tercapai hal tersebut maka diperlukan interaksi sosial yang baik sehingga terjalin komunikasi yang baik dalam mencapai perkembangan hidup bersosial. Siswa memiliki perkembangan hidup yang dinamis dan berkembang sehingga 
membutuhkan banyak sekali pembelajaran yang akan menuntunnya kepada sesuatu yang dianggapnya baik. Siswa membutuhkan bantuan dari lingkungannya sehingga siswa mampu memnuhi segala kebutuhan dalam hidupnya.

Berbagai macam perilaku yang ada di lingkungan sekolah sangat mempengaruhi kegiatan belajar mengajar. Maka dari itu telah ditemukan permasalahan yang terjadi di SMK PGRI Sukoharjo berdasarkan hasil wawancara yang dilakukan dengan guru bimbingan konseling yang mengemukakan bahwa, sering kali siswa mengalami keganjalan dalam kehidupan sosialnya. Hal tersebut ditunjukkan dengan adanya perilaku yang menyimpang saat berada disekolah, sehingga siswa memiliki berbagai macam perbuatan yang menimbulkan penilaian negatif.

Adapun perilaku menyimpang yang dialami oleh beberapa siswa memiliki tingkat kehidupan bersosial yang rendah mulai dari bersosial antar teman disekolah seperti saling mengolok-olok karena hal itu akan mengganggu proses belajar mengajar dikelas dan membuat teman yang lainnya terganggu akan hal itu. Siswa mulai berani berbohong pada guru sehingga tidak ada rasa bersalah pada dirinya bahwa menghormati dan menghargai guru adalah hal yang mulia. Permasalahan yang lainnya yakni siswa kurang pandai menempatkan diri ketika dia berkomunikasi maupun berinteraksi dengan lawan bicaranya, oleh karena itu timbul suatu masalah yang lain yakni sikap sopan santun tidak lagi tertanam pada dirinya masing-masing. Maka dari itu pentingnya meningkatkan interaksi sosial pada siswa agar siswa mampu menemukan jati dirinya dengan memberikan layanan bimbingan kelompok teknik role playing.

Menurut Tohirin (2007: 227) role playing adalah metode dengan bermain peran, dimana individu akan memerankan suatu peran tertentu dari situasi masalah sosial. Disini siswa akan melibatkan emosi, psikomotorik maupun kognisi mereka dalam memerankan suatu tokoh. Karena informasi berkaitan dengan interaksi sosial maka bisa disampaikan melalui bimbingan kelompok sehingga nantinya diharapkan dapat membentuk dan meningkatkan sikap berinteraksi pada sosial yang baik.

Penelitian ini diperkuat dengan pendapat dari Sartono (2014: 36) yang menyebutkan bahwa layanan penguasaan konten dengan teknik role playing dapat meningkatkan tanggungjawab belajar siswa, dapat dilihat hasil pengamatan pada pelaksanaan siklus I skor rata-rata yang diperoleh 2,4 dengan hasil pengamatan masih terdapat 5 siswa yang sedang dan 7 siswa yang rendah tanggungjawab belajarnya. Pada pelaksanaan siklus II terdapat perbaikan dengan cara anggota diminta menghayati baik secara perilaku maupun ucapan seperti layaknya pemain sinetron dalam layar TV dan scenario dari peneliti tanpa diberitahu, anggota diminta memainkan peran tersebut dengan baik. Pada siklus II ini pelaksanaan layanan penguasaan konten dengan teknik role playing dapat meningkatkan tanggungjawab belajar siswa, diperoleh hasil skor rata-rata yaitu 3,6. 
Hal tersebut dapat dimaknai bahwa dengan teknik role playing diharapkan para siswa mampu mengekspresikan dirinya dengan cara berinteraksi sosial yang baik dan sesuai pada nilai serta norma yang berlaku. Melalui bermain peran siswa dapat memahami peran-peran yang berbeda sehingga berbagai macam karakter dapat dipelajari dan di mainkan, dengan kata lain bermain peran mengajarkan siswa untuk mampu berkomunikasi dan memahami lingkungannya dengan cara berinteraksi yang baik.

Menurut Murtadho (2010: 16) bimbingan kelompok adalah layanan yang diselenggarakan dengan mengaktifkan dinamika kelompok untuk membahas berbagai hal yang berguna bagi pengembangan pribadi. Memfasilitasi pengembangan perasaan, pikiran, persepsi, wawasan, dan sikap yang menunjang terwujudnya tingkah laku yang lebih efektif. Menurut Mugiarso (2007: 66) layanan bimbingan kelompok yaitu "di mana siswa diajak bersama-sama mengemukakan pendapat tentang topik-topik yang dibicarakan dan mengembangkan bersama permasalahan yang dibicarakan pada kelompok, sehingga terjadi komunikasi antara individu di kelompoknya kemudian siswa dapat mengembangkan sikap dan tindakan yang diinginkan dapat terungkap di kelompok".

Menurut Tohirin (2007: 165) tujuan bimbingan kelompok dibagi menjadi dua yaitu pertama secara umum, layanan bimbingan kelompok bertujuan untuk mengembangkan kemampuan sosialisasi, khususnya kemampuan komunikasi peserta layanan (siswa). Kedua secara lebih khusus, layanan bimbingan kelompok bertujuan untuk mendorong perkembangan perasaan, pikiran, persepsi, wawasan dan sikap yang menunjang perwujudan tingkah laku yang lebih efektif, yakni meningkatkan kemampuan berkomunikasi baik verbal maupun non- verbal para siswa. Menurut Maulana (2014) Layanan bimbingan kelompok lebih bersifat preventif karena guru pembimbing lebih memfokuskan untuk mencegah munculnya permasalahan yang dapat menghambat perkembangan potensi siswa.

Dari pendapat diatas dapat disimpulkan bahwa, tujuan layanan bimbingan kelompok adalah untuk membantu memecahkan masalah-masalah umum yang sedang dihadapi siswa secara mandiri, melatih siswa dalam mengembangkan kemampuan bersosialisasi serta meningkatkan kemampuan berkomunikasi verbal dan non-verbal, sehingga siswa mampu berinteraksi dengan baik, mengemukakan pendapatnya sendiri dan tidak sekedar mengikuti pendapat orang lain. Penelitian ini memiliki tujuan melalui layanan bimbingan kelompok yakni untuk meningkatkan interaksi sosial siswa yang rendah dengan teknik role playing sehingga siswa mampu bermain peran dan mengekspresikan diri dengan lawan tokohnya.

Winkel (2012 : 568) menyatakan role playing adalah dramatisasi dari persoalan-persoalan yang dapat timbul dalam pergaulan dengan orang-orang lain, termasuk konflik-konflik yang dialami dalam pergaulan sosial. Dimana dalam melakukan role playing beberapa orang akan memegang suatu 
peranan tertentu dan memainkan suatu adegan pergaulan sosial yang mengandung persoalan yang harus diselesaikan.

Menurut Istarani (2011 : 78) kelebihan yang diperoleh dengan melaksanakan role playing adalah mengajarkan siswa supaya ia bisa menempatkan dirinya dengan orang lain, guru dapat melihat kenyataan yang sebenarnya dari kemampuan peserta didik, bermain peran dan permainan peranan menimbulkan diskusi yang hidup, peserta didik akan mengerti psikologi, model permainan peran dapat menarik minat peserta didik, dan melatih peserta didik untuk berinisiatif dan berekreasi.

Menurut Walgito (2003 : 65) interaksi sosial adalah hubungan antara individu satu dengan individu yang lain, individu satu dapat mempengaruhi individu yang lain atau sebaliknya, jadi terdapat adanya hubungan yang saling timbal balik. Hubungan tersebut dapat antara individu dengan individu, individu dengan kelompok atau kelompok dengan kelompok. Sedangkan menurut Herimanto (2008: 52) interaksi sosial adalah faktor utama dalam kehidupan sosial. Interaksi sosial merupakan hubungan sosial yang dinamis, yang menyangkut hubungan timbal balik antar individu, antar kelompok manusia, maupun antara orang dengan kelompok manusia.

Menurut Walgito (2003: 67) adapun faktor interaksi sosial yakni dengan adanya sugesti. Sugesti adalah pengaruh psikis, baik yang dating dari diri sendiri, maupun yang dating dari orang lain, yang pada umumnya diterima tanpa adanya kritik dari individu yang bersangkutan. Karena sugesti dapat dibedakan (1) auto-sugesti, yaitu sugesti terhadap diri sendiri, sugesti yang dating dati dalam diri individu yang bersangkutan, dan (2) hetero-sugesti, yaitu sugesti yang dating dari orang lain.baik auto-sugesti maupun hetero-sugesti dalam kehidupan sehari-hari memegang peranan yang penting. Adapun faktor lain adalah faktor imitasi menurut Tarde dalam Walgito (2003: 66) faktor imitasi adalah dorongan untuk meniru orang lain. Faktor imitasi ini merupakan satu-satunya faktor yang mendasari atau melandasi interaksi sosial. Peneliti menyimpulkan bahwa faktor interaksi sosial sangat mempengaruhi kehidupan individu satu dengan yang lain karena psikis manusia akan datang dengan sendirinya. Faktor interaksi sosial umumnya dapat diterima tanpa adanya kritik individu yang bersangkutan sehingga timbul beberapa faktor yang akan memengaruhi berhasil atau tidaknya suatu interaksi di dalam kehidupan sehari-harinya.

\section{METODOLOGI PENELITIAN}

Menurut Sugiyono (2010: 72) penelitian eksperimen dapat diartikan sebagai metode penelitian yang digunakan untuk mencari pengaruh perlakuan tertentu terhadap yang lain dalam kondisi yang terkendalikan. Pada penelitian ekperimen ini hanya terdapat satu kelompok (One Group pretest dan post tes), yaitu kelompok eksperimen tanpa menggunakan kelompok kontrol. Terdapat 2 proses pengukuran atau penilaian terhadap subjek dilakukan pada tahap sebelum perlakuan yakni pretest dan 
sesudah perlakuan yaitu post-test. Dalam penelitian ini perlakuan yang diberikan adalah layanan bimbingan kelompok teknik role playing karena diduga layanan bimbingan kelompok teknik role playing (X) dapat mempengaruhi interaksi sosial siswa (Y).

Sampel dalam penelitian ini mengambil sebagian sampel satu kelas yaitu X MM (Multimedia), yang selanjutnya diambil siswa dengan interaksi sosial yang sangat rendah berdasarkan penyebaran angket yang disusun peneliti. Teknik purposive sampling, dengan menggunakan pertimbangan tertentu ini yaitu mencari siswa yang memiliki interaksi sosial yang kurang.

Teknik pengumpulan data dengan angket. Jenis angket yang digunakan yakni tertutup (rating scale). Angket ini memiliki tujuan untuk mengetahui tingkat interaksi sosial siswa dalam mengisi angket yang sesuai kebutuhannya. Validitas instrument menggunakan rumus Product Moment, sedangkan reliabilitas menggunakan rumus Spearman Brown. Uji Hipotesis dengan melakukan uji beda berbantuan statistik nonparametris Wilcoxon.

\section{PEMBAHASAN}

\section{KONDISI AWAL INTERAKSI SOSIAL}

Dari pre test tersebut maka peneliti mengambil subyek penelitian sebanyak beberapa siswa. Pemilihan ini dilakukan dengan cara memilih subyek dengan perolehan nilai pre test yang sangat rendah. Hasil pre tes beberapa siswa yang dijadikan sampel penelitian sebagai berikut, Tabel 1. Hasil Pre test Interaksi Sosial

\begin{tabular}{lcl}
\hline \multicolumn{1}{c}{ Nama } & Prosentase & Kategori \\
\hline M1 & $40 \%$ & Sangat rendah \\
M8 & $42 \%$ & Sangat rendah \\
M9 & $40 \%$ & Sangat rendah \\
M10 & $42 \%$ & Sangat rendah \\
M14 & $42 \%$ & Sangat rendah \\
M15 & $41 \%$ & Sangat rendah \\
M17 & $41 \%$ & Sangat rendah \\
M20 & $40 \%$ & Sangat rendah \\
M25 & $42 \%$ & Sangat rendah \\
M26 & $42 \%$ & Sangat rendah \\
\hline Rata-rata & $41,2 \%$ & Sangat rendah \\
\hline
\end{tabular}

Kondisi awal interaksi sosial tergolong kriteria sangat rendah, hal ini sesuai dengan fakta di sekolah. Siswa masih jarang terjalin hubungan baik antar siswa, komunikasi yang akrab dan hangat juga belum nampak. Peneliti berasumsi bahwa siswa perlu adaptasi terhadap sekolah yang baru, karena siswa masih di kelas X SMK. Keseluruhan sampel peelitian akan diberikan perlakuan yaitu bimbingan kelompok teknik role playing. 


\section{Kondisi Akhir Interaksi Sosial}

Layanan bimbingan kelompok teknik role playing diikuti oleh semua sampel penelitian. Terjadi peningkatan skor presentase interaksi sosial pada seluruh sampel. Berikut distribusi presentase post test sampel penelitian:

Tabel. 2 Hasil Post Test Interaksi Sosial

\begin{tabular}{lcc}
\hline \multicolumn{1}{c}{ Nama } & Prosentase & Kategori \\
\hline M1 & $63 \%$ & Sedang \\
M8 & $63 \%$ & Sedang \\
M9 & $63 \%$ & Sedang \\
M10 & $79 \%$ & Sedang \\
M14 & $63 \%$ & Sedang \\
M15 & $65 \%$ & Sedang \\
M17 & $69 \%$ & Sedang \\
M20 & $66 \%$ & Sedang \\
M25 & $65 \%$ & Sedang \\
M26 & $65 \%$ & Sedang \\
\hline Rata-rata & 66,1 & Sedang \\
\hline
\end{tabular}

Kondisi akhir interaksi sosial siswa mengalami peningkatan dari kriteria sangat rendah ke sedang dengan peningkatan presnetase sebesar 24,9. Peningkatan ini dipengaruhi oleh skenario drama yang dirancang oleh penulis. Naskah ini bertemakan tentang konflik antara guru dengan murid. Diharapkan dengan kegiatan ini subyek lebih aktif dan berani untuk tampil didepan umum, dan dapat mengetahui potensi apa yang ada di dalam dirinya. Peneliti dan subyek berdiskusi mengenai tema, alur cerita, dan pemilihan tokoh. Kemudian subyek diminta untuk melakukan uji coba terlebih dahulu.

Pada pertemuan lainnya bertemakan sikap toleransi antar sesama. Pada pertemuan kedua terlihat ada perubahan pada subyek, subyek telah aktif dan tidak malu untuk tampil sehingga dengan materi yang telah ditentukan oleh pemimpin kelompok terkait interaksi sosial siswa mampu peduli dan mudah untuk berkomunikasi kepada lawan bicaranya. Setelah kegiatan presentasi subyek diajak untuk berdiskusi dan membuat kesimpulan. Subyek terlihat sangat aktif dan antusias ketika berdiskusi, membuat kesimpulan, dan membahas kegiatan selanjutnya.

Terjalinnya komunikasi antar siswa dalam drama membantu berkembangnya kemampuan berosialisasi siswa. Menurut Maulana (2016) Kemampuan berkomunikasi merupakan salah satu syarat dalam berinteraksi dengan orang lain. Melalui komunikasi, seseorang bisa menjalin hubungan dan mengembangkan kemampuan sosialnya. Hal tersebut merupakan indikator terwujudnya interaksi sosial siswa. Siswa mampu bermain peran sesuai dengan naskah yang telah diberikan oleh pemimpin kelompok. Sehingga siswa mampu memahami setiap kalimat yang mereka perankan serta 
menggunakan mimik wajah yang cukup baik. Maka dari itu anggota kelompok yang memerankan naskah drama telah mengambil hikmah dari isi dan tujuan tersebut.

Interaksi sosial bagi siswa sangat mempengaruhi perilaku, kemampuan komunikasi, dan kemampuan berfikir. Hal tersebut didukung penelitian yang dilakukan oleh Carter dalam Maulana (2016) menghasilkan bahwa dukungan intervensi sebaya akan mempengaruhi interaksi sosial siswa, intervensi akan menimbulkan rangsangan untuk mengembangkan komunikasi antar siswa dan mempengaruhi hasil belajarnya. Maulana (2016) Hal tersebut menandakan bahwa pentingya komunikasi bagi siswa, tidak hanya berdampak kepada kemampuan sosialnya tetapi juga bepengaruh terhadap kemampuan akademiknya. Meskipun dampak terhadap kemampuan akademik tidak secara langsung dapat dirasakan bagi mahasiswa, namun setidaknya memberikan dampak yang positif bagi perkembangan masing-masing pribadi mahasiswa.

Interaksi sosial yang positif yang mendukung terciptanya hubungan sosial yang kondusif dan hangat antar siswa. Siswa yang masuk kategori masa remja sering kali terlibat dalam konflik dan perlak menyimpang. Hal tersebut juga merupakan cara siswa berinteraksi dengan lingkungan namun yang bersifat negatif. Maulana (2019) Penurunan intensitas perilaku kenakalan remaja didorong dengan pengondisian lingkungan sekolah dan rumah yang mampu memberikan contoh siswa dalam berperilaku sesuai dengan norma di masyarakat. Kenakalan remaja sebagai bentuk siswa mengeksplorasi kemampuan dalam memerankan sesuai gender dan mencari identitas diri dengan cara mengidentifikasi perilaku di sekitarnya. Penyesuaian perilaku remaja memerlukan proses untuk memperoleh perangkat nilai yang diyakini oleh masyarakat.

Layanan Bimbingan kelompok teknik role playing dapat meningkatkan interaksi sosial dikarenakan layanan ini memiliki tahap-tahap yang dimana kegiatan tersebut dapat terstruktur yakni dengan tahap awal sampai dengan tahap pengakhiran. Sehingga teknik role playing dapat memberikan kesan yang menarik dimana anggota kelompok telah memerankan naskah drama yang sesuai dengan masalah yang diangkat oleh penulis yakni tentang kehidupan interaksi sosial.

Layanan bimbingan kelompok teknik role playing telah memberikan pengaruh yang baik dengan memfasilitasi pengembangan perasaan, pikiran, persepsi, wawasan, dan sikap yang menunjang terwujudnya tingkah laku yang lebih efektif. Contoh perilaku efektif pada siswa yakni dengan mewujudkan sikap sopan santun, menghargai pendapat, serta toleransi pada lingkungan disekitarnya. Adapun hal yang dilakukan oleh siswa pada lingkungannya sangat mempengaruhi interaksi yang terjalin dan akan membawa dampak pada kehidupannya dan kehidupan orang lain. Hal yang membuat siswa mengalami peningkatan yakni siswa telah bersungguh-sungguh melaksanakan layanan bimbingan kelompok teknik role playing dengan baik dan disiplin. Dapat dilihat dari proses 
bermain peran dan membaca serta mengekspresikan diri melalui naskah drama yang telah ditentukan oleh peneliti.

\section{SIMPULAN}

Perbandingan hasil pre tes dan post tes dianalisis menggunakan uji statistik Wilcoxon dengan taraf signifikansi 5\% hasilnya bahwa 0,005 lebih kecil dari 0,05 dengan nilai Z Hitung yang didapat sebesar -2,807 dan nilai $\mathrm{Z}$ tabel 1,598. Hasil hipotesisnya yaitu ha diterima dan ho ditolak. Artinya, terdapat pengaruh layanan bimbingan kelompok teknik role playing (bermain peran) terhadap interaksi sosial pada siswa kelas X MM Sekolah Menengah Kejuruan PGRI Sukoharjo Tahun Ajaran 2017/2018. Peneliti selanjutnya, diharapkan untuk dapat melaksanakan treatment lebih dari 2 kali sehingga dampak perubahan dapat meningkat secara signifikan. Dan ruang lingkup yang diteliti lebih dari satu kelas sehingga dapat memberikan banyak gambaran permasalahan yang lebih luas. pemberian layanan bimbingan kelompok dengan berbagai macam teknik yang menarik bagi siswa. Pemberian layanan dirancang sevariatif mungkin sehingga para siswa tidak merasa bosan karena terlalu monoton dalam pemberian materi yang disampaikan. Diharapkan layanan bimbingan kelompok teknik role playing (bermain peran) atau metode belajar lainnya dapat dilakukan hal ini dikarenakan teknik ini bukan hanya menyelesaikan materi saja, akan tetapi juga dapat memotivasi siswa, membuat siswa lebih aktif dan mengurangi kejenuhan pada waktu melaksanakan proses belajar mengajar. 


\section{DAFTAR PUSTAKA}

Herimanto. (2010). Ilmu Sosial \& Budaya Dasar. Jakarta : Bumi Aksara.

Istarani. (2011). Model Pembelajaran Inovatif. Medan : Media Persada.

Maulana, M., Wibowo, M., \& Tadjri, I. (2014). Model Bimbingan Kelompok Berbasis Budaya Jawa Dengan Teknik Permainan Untuk Meningkatkan Interaksi Sosial Siswa Smp Kota Semarang. Jurnal Bimbingan Konseling, 3(2). Retrieved from https://journal.unnes.ac.id/sju/index.php/jubk/article/view/4612

Maulana, M., Hidayati, A. (2016). Penggunaan Layanan Bimbingan Kelompok Teknik Diskusi Untuk Meningkatkan Kemampuan Komunikasi Interpersonal Mahasiswa Bimbingan Dan Konseling Univet Bantara Sukoharjo Angkatan Tahun 2015/2016. Edudikara: Jurnal $\begin{array}{lllll}\text { Pendidikan dan } & \text { Pembelajaran, } & \text { Retrieved }\end{array}$ https://ojs.iptpisurakarta.org/index.php/Edudikara/issue/view/10

Maulana, M., Nugroho, P. (2019). Mengurangi Kenakalan Remaja Menggunakan Konseling Behavioral Pada Peserta Didik di SMA. Konseli: Jurnal Bimbingan dan Konseling, 6(1). Retrieved from http://ejournal.radenintan.ac.id/index.php/konseli/article/view/4059/2941

Mugiarso, Heru. (2007). Bimbingan dan Konseling.Semarang: UNNES Press

Murtadho Ali. (2010). Modul Pengembangan Pribadi Konselor, Semarang : IKIP PGRI.

Prayitno. (2004). Layanan Bimbingan Kelompok dan Konseling Kelompok. Padang Sugiyono. (2010). Metode Penelitian Kuantitatif Kualitatif dan $R \& D$. Bandung : Alfabeta.

Tohirin. (2007). Bimbingan Konseling Di Sekolah dan Madrasah (Berbasisi Integrasi), Jakarta : PT. Raja Grafindo Persada

Walgito, Bimo. (2003). Psikologi Sosial (Suatu Pengantar). Yogyakarta : Andi Offset

W.S Winkel dan Sri Hastuti. (2012). Bimbingan dan Konseling di Institusi Pendidikan, Yogykarta: Media Abadi.

Sartono. Y. (2014). Peningkatan Tanggungjawab Belajar Melalui Layanan Penguasaan Konten Dengan Teknik Role Playing. Jurnal Penelitian Tindakan Kelas. Vol. 16 No. 2. 